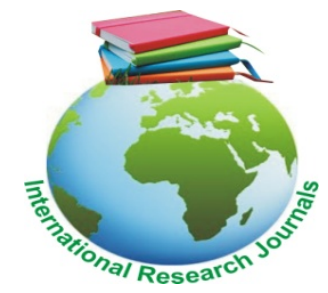

African Journal of Food Science and Technology (ISSN: 2141-5455) Vol. 6(5) pp. 131-135, August, 2015 Available online @http://www.interesjournals.org/AJFST

DOI: http:/dx.doi.org/10.14303/ajfst.2015.051

Copyright @2015 International Research Journals

Full Length Research Paper

\title{
Flavonoid profile, anthocyanin, carotenoid, sugar and vitamin compositions of Lonchocarpus sericeus seeds
}

\author{
Oyedeji O. A. ${ }^{1 *}$, Azeez L. ${ }^{2}$, Adewuyi S.O. ${ }^{3}$ Osinfade B.G. ${ }^{1}$ and Bamimore M.O ${ }^{1}$ \\ ${ }^{1}$ Department of Science Laboratory Technology, The Federal Polytechnic, Ilaro, Nigeria \\ ${ }^{2}$ Analytical, Environmental and Nutritional Chemistry Research Laboratory, Department of Chemical Sciences, Osun \\ State University, Osogbo, Nigeria \\ ${ }^{3}$ Department of Pure and Applied Chemistry, Ladoke Akintola University of Technology, Ogbomoso, Nigeria \\ ${ }^{*}$ Corresponding author: abdulrasaq2008@yahoo.com, +2348055186225
}

\begin{abstract}
This study reports analyses of flavonoid profile, anthocyanin, sugar, carotenoid and vitamin compositions in Lonchocarpus sericeus (L. sericeus) seeds. Flavonoid profile, anthocyanin, sugar, carotenoid were determined with gas chromatography coupled with flame ionization detector (GC-FID) while vitamins were determined using pulse flame photometric detector (GC-PTPD). Total flavonoid concentration of $L$. sericeus seeds was $815.86 \mathrm{mg} / 100 \mathrm{~g}$ and its profile consists of flavonol $(72.5 \%)$, flavanones $(19.3 \%)$, flavones $(7.25 \%)$, flavanol $(0.93 \%)$ and isoflavones $(0.02 \%)$. Quercetin was the most abundant with $28.8 \%$. L. sericeus seeds composed of $80.5 \%$ disaccharides and $19.5 \%$ monosaccharide with sucrose having $80.4 \%$ abundance. Total vitamin, carotenoid and anthocyanin contents of the seeds were $70.32 \mathrm{mg} / 100 \mathrm{~g}, 102.18 \mu \mathrm{g} / 100 \mathrm{~g}$ and $12.18 \mathrm{mg} / 100 \mathrm{~g}$ respectively. Vitamin $\mathrm{E}$ $(33.3 \%), \beta$-carotene $(65.4 \%)$ and cyanin $(30.3 \%)$ had highest abundance in vitamins, carotenoids and anthocyanins respectively. These results show that the seeds of $L$. sericeus have intrinsic sweetness and can scavenge for free radicals.
\end{abstract}

Keywords: flavonols, disaccharides, fat soluble vitamins, quercetin, anthocyanins

\section{INTRODUCTION}

Lonchocarpus sericeus (L. sericeus) is a leguminous plant commonly called a cube root or Senegal lilac. It is a dry deciduous tree that can grow from 10 to 16 meters high and flowers with dense hanging racemes of purple flowers which makes it perfect for display purposes. The flowers have a marked smell similar to vanilla. It is frequently planted in villages as a shade tree and in gardens and commentaries. The wood is clear yellow, sometimes marbled, with heart-wood and olive-green (Kojs et al, 2004; Musa et al, 2006; Adewuyi et al, 2012). The bark strips easily and is a good source of fiber. $L$. sericeus has been reported to possess antioxidant, antifungi and insect-repellant properties. It is used in the treatment of epilepsy, laxative, to stimulate appetite and to treat stomach disorder in Africa. It also has common application in treatment convulsions and back aches (Kojs et al, 2004; Fontenele et al, 2005; Ezeagu and Gowda). Phytochemicals such as alkaloids, saponins, carotenoids, flavonoids, tannins, triterpenes and steroids have been detected in the methanol extracts of the stem bark, seeds and root (Musa et al, 2006) but anthocyanin, vitamins and carotenoids which have been shown to be hepatoprotective, anti-inflammatory, antiviral, free radical scanvengers have not been reported (Lohachoompo et al, 2004; Kelebek et al, 2009; Okiei et al, 2009; Afify et al, 2012). Study conducted by Ezeagu and Gowda (2006) showed that $L$. sericeus is a source of leucine and lysine which are essential amino acids. Physicochemical properties and fatty acid composition of $L$. sericeus seed oil reveled high quantity of oil and unsaturated fatty acids 
which make the oil from the seeds a suitable feed stock for the production of lubricants (Adewuyi et al, 2012). Despite these, little or no study has reported flavonoid profile, anthocyanin, sugar, carotenoid and vitamin compositions of $L$. sericeus seeds. These amongst other compositions are important parameters to establish health functions food products such as seeds. Therefore, this study was designed to determine the nutritional compositions and phytochemicals of $L$. sericeus seeds.

\section{MATERIALS AND METHODS}

\section{Seed Samples}

Mature seeds were collected from a tree within the premises of the Federal Polytechnic, Ilaro $\left(6.89^{\circ} \mathrm{N}, 3.02^{\circ} \mathrm{E}\right)$ between April and August, 2013. The seeds were washed with deionized-distilled water and then ovendried at $60{ }^{\circ} \mathrm{C}$. The dried seeds were pulverized using a blender, sieved and kept in an air tight container for further analysis.

\section{Determination of flavonoid composition}

The procedures described by Whitehead et al. (1983) and Provan et al. (1994) were used for the extraction of flavonoids from L.sericeus. Briefly, $50 \mathrm{mg}$ of the sample was extracted with $5 \mathrm{ml}$ of $1 \mathrm{M} \mathrm{NaOH}$ for $16 \mathrm{~h}$ on a shaker at ambient temperature. After this, the extract was centrifuged $(5000 \mathrm{~g})$. The residue was rinsed with deionized water, centrifuged again and the combined supernatants were placed in a disposable glass test tube which was heated at $90{ }^{\circ} \mathrm{C}$ for $2 \mathrm{~h}$ to release conjugated flavonoids. The heated extract was cooled, titrated with 4 $\mathrm{M} \mathrm{HCL}$ to $\mathrm{pH}<2.0$, diluted to $10 \mathrm{ml}$, with deionised water, and centrifuged to remove the precipitate. $15 \mathrm{ml}$ of the supernatant obtained was passed through a conditioned Varian (Varian Assoc., Habor City, CA) Bond Elut PPL (3$\mathrm{ml}$ size with $200 \mathrm{mg}$ packing) solid- phase extraction tube at $5 \mathrm{ml} \mathrm{min}^{-1}$ attached to a Visiprep (Supelco, Bellefonte, $P A)$. The tubes were then placed under vacuum (-60 $\mathrm{kPa}$ ) until the resin was thoroughly dried after which the flavonoids were eluted with $1 \mathrm{~mL}$ of ethyl vials. The PPL tubes were conditioned by first passing $2 \mathrm{~mL}$ of ethyl acetate followed by $2 \mathrm{ml}$ water $(\mathrm{pH}<2.0)$.

The composition of flavonoid in purified $L$. sericeus extract was analyzed using gas chromatography coupled with flame ionization detector (GC-FID). $1 \mu \mathrm{l}$ of each solution was injected into GC (Hewlett-Packard Model 5890, USA) with FID which has HP-1 column (30 m x $0.25 \mu \mathrm{m} \times 0.25 \mathrm{~mm}$ id), nitrogen carrier gas, a detector section temperature of $320{ }^{\circ} \mathrm{C}$ and a split ratio (20:1) mode inlet section $\left(250{ }^{\circ} \mathrm{C}\right)$. The column was initially at $60{ }^{\circ} \mathrm{C}$ held for $5 \mathrm{~min}$ and increased at $15^{\circ} \mathrm{C} / \mathrm{min}$ for 15 min, maintained for $1 \mathrm{~min}$ and at $10^{\circ} \mathrm{C} / \mathrm{mi}$ for $4 \mathrm{~min}$ held for 2 min. Flavonoids obtained were compared with their standards which were analyzed before the samples.

\section{Determination of anthocyanin composition}

$5 \mathrm{~g}$ of $L$. sericeus was extracted with $100 \mathrm{ml}$ of $1 \% \mathrm{HCl}$ in $\mathrm{MeOH}$ and was placed in an orbital shaker for $4 \mathrm{hr}$. The solution was filtered with Whatman No. 4 filter paper and filtrate was evaporated at $40{ }^{\circ} \mathrm{C}$ to dryness using a rotary evaporator. $2 \mathrm{~g}$ each of $L$. sericeus extract was dissolved in $100 \mathrm{ml}$ methanol. The mixture was stirred thoroughly for gas chromatography coupled with flame ionization detector (GC-FID) analysis. 1 $1 \mu \mathrm{l}$ of each solution was injected into GC (Hewlett-Packard Model 5890, USA) with FID which has SupelCoWax 10 column (30 m x 0.25 $\mu \mathrm{m} \times 0.25 \mathrm{~mm} \mathrm{id}$ ), hydrogen carrier gas, a detector section temperature of $320{ }^{\circ} \mathrm{C}$ and a split ratio (20:1) mode inlet section $\left(250{ }^{\circ} \mathrm{C}\right)$. The column was initially at $45^{\circ} \mathrm{C}$ held for $2 \mathrm{~min}$ and increased at $30^{\circ} \mathrm{C} / \mathrm{min}$ to $60^{\circ} \mathrm{C}$ for $2 \mathrm{~min}$, at $2{ }^{\circ} \mathrm{C} / \mathrm{min}$ to $160^{\circ} \mathrm{C}$ and at $5^{\circ} \mathrm{C} / \mathrm{min}$ to $230{ }^{\circ} \mathrm{C}$ for $20 \mathrm{~min}$. Different anthocyanins were identified by their peaks.

\section{Determination of carotenoid composition}

The carotenoid composition was analyzed using modified method of extraction of Takagi (1985). $5 \mathrm{~g}$ of the pulverized sample was homogenized in $75 \mathrm{ml}$ of acetone and kept at room temperature for $1 \mathrm{~h}$ in the dark. The homogenate was filtered through Whatman No. 4 filter paper by suction. Extraction was repeated three times with the same volume of acetone. The extracts were combined and evaporated under reduced pressure and the residue was re- extracted by a mixture of diethyl ether and petroleum ether in equal ratio. The extract was evaporated using rotary evaporator. Then the concentrated extract was dried of water by using the anhydrous sodium sulphate before gas chromatography analysis. Dried extract was dissolved in methanol for gas chromatography coupled with flame ionization detector (GC-FID). $1 \mu \mathrm{l}$ of the methanolic extract was injected into GC (Hewlett-Packard Model 5890, USA) with FID which has AC- 5 column $(30 \mathrm{~m} \times 0.25 \mu \mathrm{m} \times 0.25 \mathrm{~mm}$ id), nitrogen carrier gas, a detector section temperature of $320{ }^{\circ} \mathrm{C}$ and a split ratio (20:1) mode inlet section (250 ${ }^{\circ} \mathrm{C}$ ). The column was initially at $60{ }^{\circ} \mathrm{C}$, increased at 10 ${ }^{\circ} \mathrm{C} / \mathrm{min}$ for $20 \mathrm{~min}$, maintained for $20 \mathrm{~min}$ and at $15^{\circ} \mathrm{C}$ for $4 \mathrm{~min}$ and maintained for $4 \mathrm{~min}$

\section{Determination of sugar composition}

$50 \mathrm{mg}$ of the dried extract of $L$. sericeus was derivatised using Silylation process. Tetramethyl silyl (TMS) group replaced active hydrogen on the compounds after the treatment with the derivatization reagent. The content was concentrated to $1 \mathrm{ml}$ for gas 
Table 1. Flavonoid composition of $L$. serceus seed

\begin{tabular}{ll}
\hline Flavonoids & Composition $(\mathrm{mg} / 100 \mathrm{~g})$ \\
\hline Flavonol & \\
\hline Quercetin & 234.67 \\
Kaempferol & 172.39 \\
Galangin & 145.30 \\
Myricetin & 32.74 \\
Isorhamnetin & 6.08 \\
Morin & 0.04 \\
\hline Flavones & \\
\hline Apigenin & 59.06 \\
Luteolin & 0.08 \\
Acacetin & 0.02 \\
\hline Isoflavones & \\
\hline Genistein & 0.2 \\
Daidzein & 0.19 \\
Biochanin & 0.07 \\
\hline Flavanones & \\
\hline Naringenin & 98.26 \\
Naringenin glycoside & 59.09 \\
Nobiletin & 0.05 \\
Hesperetin & 0.04 \\
\hline Flavanol & \\
\hline (-)-Epicatechin-3-gallate & 1.31 \\
(-)-Epigallocatechin-3-gallate & 1.01 \\
(+)-Catechin & 5.11 \\
(+)-Gallocatechin & 0.02 \\
(-)-Epicatechin & 0.13 \\
&
\end{tabular}

chromatography analysis and $1 \mu \mathrm{l}$ was injected into the injection port of gas chromatography (GC HewlettPackard Model 5890, USA) with FID which has BPX70 column $(12 \mathrm{~m} \times 0.32 \mathrm{~mm} \times 0.25 \mu \mathrm{m}$ i.d) isothermally set at $210{ }^{\circ} \mathrm{C}$ with hydogen carrier gas. A detector section temperature of $325{ }^{\circ} \mathrm{C}$, split ratio $(50: 1)$ and inlet temperature $\left(250{ }^{\circ} \mathrm{C}\right)$ were used.

\section{Vitamin Composition}

Vitamins (A, D, E, K, B1, B2, B3, B5, B6, B9 and C) in L. sericeus seeds were determined accordingto Association of Analytical Chemists' [15] method. $1 \mu \mathrm{l}$ of the extract was injected into the injection port of gas chromatography (HP 6890) coupled with pulse flame photometric detector (GC-PFPD) with a column HP $(30 \mathrm{~m} \times 0.25 \mu \mathrm{m} \times 0.255$ $\mathrm{mm}$ id) to obtain individual peaks of each vitamin. The carrier gas was nitrogen and the inlet temperature was $250{ }^{\circ} \mathrm{C}$ while the detector temperature was $320^{\circ} \mathrm{C}$. The column temperature was initially at $50{ }^{\circ} \mathrm{C}$ held for $2 \mathrm{~min}$ and increased at the rate of $10{ }^{\circ} \mathrm{C} / \mathrm{min}$ for $20 \mathrm{~min}$, maintained for $4 \mathrm{~min}$ and held at the rate of $20^{\circ} \mathrm{C} / \mathrm{min}$ to $320{ }^{\circ} \mathrm{C}$ for $2 \mathrm{~min}$.

\section{RESULTS AND DISCUSSION}

\section{Flavononoid composition}

Table 1 shows the composition of flavonoids in $L$. sericeus seeds. Total flavonoid concentration of $L$. sericeus seeds was $815.86 \mathrm{mg} / 100 \mathrm{~g}$ and their relative abundance followed; flavonol (72.5\%), flavanones (19.3
$\%)$, flavones $(7.25 \%)$, flavanol $(0.93 \%)$ and isoflavones (0.02\%). Quercetin was the most abundant with $28.8 \%$ while the least abundant were acacetin and (+)gallocatechin $(0.002 \%)$. High abundance of kaemferol, galangin, naringenin, naringenin glucoside, apigenin and myricetin was also obtained in this order.

Quercetin which is the most abundant flavonoid in the seeds has been reported to be the most biologically, pharmaceutically active and most common dietary flavonoid (Malešev and Kunti, 2007; Bukhari et al, 2008). Quercetin is an effective metal chelator and contributes significantly to the anti-bacterial and anti-inflammatory actions of flavonoids. Also, it has been reported to be antioxidative, anticarcinogenic, anti-aggregatory and vasolidating (Erlund, 2004). This shows that $L$. sericeus seeds can act as sources for free radicals scavengers (Azeez et al, 2012).

Table 2 presents the composition of anthocyanin in $L$. sericeus seeds. The total anthocyanins determined were $12.18 \mathrm{mg} / 100 \mathrm{~g}$ with cyanidin having highest abundance (30.3\%). The relative abundance of anthocyanin components followed cyaniding $>$ delphinidin $>$ peonidin $>$ pelargonidin $>$ malvidin $>$ petunidin. Cyanidin has been reported to be the most common anthocyanin in red flowers (Harborne and Williams, 2000), thus, L. sericeus seeds could have intrinsic red colour.

Table 3 presents the results of carotenoid composition of $L$. sericeus seeds. Total carotenoid content was $102.18 \mu \mathrm{g} / 100 \mathrm{~g}$ with $\beta$-carotene having the highest abundance of $65.4 \%$. The relative abundance of carotenoids followed $\beta$-carotene $(65.4 \%)>\beta$ cryptoxanthin $\quad(26.6 \%)>$ 
134 Afr. J. Food Sci. Technol.

Table 2. Anthocyanin composition of $L$. serceus seed

\begin{tabular}{ll}
\hline Anthocyanin & Composition $(\mathrm{mg} / 100 \mathrm{~g})$ \\
\hline Cyanidin & 3.69 \\
Delphinidin & 2.73 \\
Malvidin & 0.97 \\
Peonidin & 2.24 \\
Petunidin & 0.32 \\
Pelargonidin & 2.23 \\
\hline
\end{tabular}

Table 3. Carotenoid composition of $L$. serceus seed

\begin{tabular}{ll}
\hline Carotenoid & Composition $(\mu \mathrm{g} / 100 \mathrm{~g})$ \\
\hline B-cryptoxanthin & 27.22 \\
Lycopene & 3.32 \\
ß-carotene & 66.81 \\
Anthera-xanthin & 2.05 \\
Asta-xanthin & 2.20 \\
Neo-xanthin & 0.05 \\
Viola-xanthin & 0.50 \\
Xanthophyll & 0.03 \\
\hline
\end{tabular}

Table 4. Sugar composition of $L$. serceus seed

\begin{tabular}{ll}
\hline Sugar & Composition $(\mathrm{mg} / 100 \mathrm{~g})$ \\
\hline Monosaccharide & \\
\hline Ribose & 0.21 \\
Xylose & 0.12 \\
Arabinose & 0.22 \\
Rhamnose & 0.07 \\
Fructose & 7.20 \\
Glucose & 75.17 \\
\hline Disaccharide & \\
\hline Maltose & 0.21 \\
Lactose & 0.17 \\
Sucrose & 342.08 \\
\hline
\end{tabular}

Table 5. Vitamin composition of $L$. serceus seed

\begin{tabular}{ll}
\hline Vitamins & Composition $(\mathrm{mg} / 100 \mathrm{~g})$ \\
\hline Fat-Soluble & \\
\hline A & 3.89 \\
D & 12.04 \\
E & 23.42 \\
K & 4.07 \\
\hline Water Soluble & \\
\hline B3 & 5.33 \\
B6 & 4.16 \\
B5 & 8.20 \\
B1 & 0.29 \\
B2 & 0.07 \\
B9 & 0.71 \\
C & 8.14 \\
\hline
\end{tabular}

lycopene $(3.2 \%)>$ asta-xanthin $(2.2 \%)>$ anther-xanthin $(2.01 \%)>$ neo-xanthin $(0.49 \%)>$ viola-xanthin $=$ xanthophyl $(0.05 \%)$.

Carotenoids such as lycopene and $\beta$-carotene have shown inverse relationship with incidence of cancer and have been proved to possess antioxidant activity due to their ability to quench singlet oxygen, detoxify free radicals and inhibit lipid peroxidation (Sarada et al, 2002; Erlund, 2004). High concentration of $\beta$-carotene shows that $L$. sericeus seeds are capable of scavenging singlet oxygen and detoxify radicals (Azeez et al, 2012).

The results of sugar compositions in $L$. sericeus seeds are presented in table 4 . The total amount of sugar in $L$. sericeus seeds was $425.45 \mathrm{mg} / 100 \mathrm{~g}$. The seeds 
composed of $80.5 \%$ disaccharides and $19.5 \%$ monosaccharide with sucrose having $80.4 \%$ abundance. The ratio of reducing sugars to non-reducing sugars is 1 : 4. Also, the ratio of sucrose : glucose : fructose is 47.5 : $10.4: 1$. With high content of sucrose in $L$. sericeus seeds, it shows that the seeds are a good source of energy and contain intrinsic sweetness (Kelebek et al, 2009)

Table 5 shows the composition of vitamins in $\mathrm{L}$. sericeus. Total vitamin content of the seeds was 70.32 $\mathrm{mg} / 100 \mathrm{~g}$ having $61.7 \%$ fat-soluble vitamins and $38.3 \%$ water-soluble vitamins. Vitamin $\mathrm{E}$ was the most abundant with $33.3 \%$ and vitamin B2 was the least abundant with $0.1 \%$.

Vitamin $E$ is a fat soluble vitamin which is known to have several biological functions of which the most important are its antioxidant function and prevention of lipid peroxidation (Shin et al, 2003). Vitamins C and E have been reported to help body fight against free radicals (Okiei et al, 2009; Azeez et al, 2012).

\section{CONCLUSION}

This study has reported the analyses of flavonoid profile, anthocyanin, carotenoid, sugar and vitamin compoistions of $L$. sericeus seeds. The seeds are a good source of antioxidant with high free radical scavenging ability due to high concentrations of flavonoids, $\beta$-carotene and vitamin $E$ obtained. The seeds could also serve as sources of nutrients and energy as shown by their sygar contents and compositions

\section{REFERENCES}

Adewuyi A, Oderinde RA, Rao BVSK, Prasad RBN (2012). Chemical Composition and Molecular Speciation of the Triacylglycerol of the Oils of Lonchocarpus sericeus and Lonchocarpus cyanescens. Nat. Prod. Res. 26(20), 1954-1956.

Afify AMR, El-Beltagi HS, Abd El-Salam SM, Omran AA (2012). Biochemical changes in phenols, flavonoids, tannins, vitamin $E, \beta-$ carotene and antioxidant activity during soaking of three white sorghum varieties. Asian Pac. J. Trop. Biomed. 203-209

AOAC (2006). Official Methods of Analysis. $18^{\text {th }}$ Edition. The Association of Official Analytical Chemists, Arlington, USA.

Azeez L, Adeoye M.D, Majolagbe TA, Lawal AT, Badiru R(2012). Antioxidantactivity and phytochemical contents of some selected Nigerian fruits and vegetables. Ame. J. Chem.2(4), 209-213
Azeez L, Adeoye MD, Ganiyu OT, Abdul-salami IO, Majolagbe TA, Lawal AT (2012). Influence of microbial contamination on antioxidant composition and free radicals scavenging effects of fresh and decaying spices. Fountain J. Nat. Appl. Sci.1(1), 5564Bukhari SB, Memona S, Tahir MM, Bhanger MI (2008). Synthesis, characterization and antioxidant activity of cobaltquercetin complex. J. Mol. Str. 892, 39-46

Erlund I (2004). Review of the flavonoids quercetin, hesperetin, and naringenin, Dietary sources, bioactivities, bioavailability and epidemiology. Nutr. Res. 24, 851-874

Ezeagu IE, Gowda LR (2006). Protein extractability, fractionation and amino acid composition of some leguminous seeds Found in Nigeria. J. Food Biochem. 30, 1-11

Fontenele JB, Leal LKAM, Ferreira MAD, Silveira ER, Viana GSB (2005). Antiplatelet Effect of Lonchocarpin and Derricin Isolated from Lonchocarpus sericeus. Pharm. Bio. 43 (8), 726-731

Harborne JB, Williams CA (2000). Advances in flavonoid research since 1992. Phytochem. 55, 481-504

Kelebek H, Selli S, Canbas A, Cabaroglu T (2009). HPLC determination of organic acids, sugars, phenolic compositions and antioxidant capacity of orange juice and orange wine made from a Turkish cv. Kozan. Microchem. J. 91, 187-192

Kojs P, Włoch W, Rusin A (2004). Rearrangement of cells in storeyed cambium of Lonchocarpus sericeus (Poir.) DC connected with formation of interlocked grain in the xylem. Trees. 18, 136-144

Lohachoompo V, Srzednicki G, Craske J (2004). The Change of Total Anthocyanins in Blueberries and Their Antioxidant Effect After Drying and Freezing. J. Biomed. Biotech. 5, 248-252

Malešev D, Kunti V (2007). Investigation of metal-flavonoid chelates and the determination of flavonoids via metal-flavonoid complexing reactions. J. Serb. Chem. Soc. 72(10): 921-939

Musa AM, Yaro AH, Abubakar MS (2006). Anticonvulsant activity of methanol extract of the stem bark of Lonchocarpus sericeus Poir (Papilionaceae). J. Trop. Biosci. 6, 17-30

Okiei W, Ogunlesi M, Azeez L, Osunsanmi M, Obakachi V, Golda N (2009). The voltammetric and titrimetric determination of ascorbic acid levels in tropical fruit samples. Inter. J. Electrochem. Sci. (4), 276-287.

Provan GJ, Scobbie L, Chesson A (1994). Determination of phenolic acids in plant cell walls by microwave digestion. J. Sci. Food Agric. 64, 63-65

Sarada SKS, Dipti P, Anju B, Pauline T, Kain AK, Sairam M, Sharma SK, llavazhagan G, Kumar D, Selvamurthy W (2002). Antioxidant effect of beta-carotene on hypoxia induced oxidative stress in male albino rats: J. Ethnopharma. 79, 149-153

Shin SJ (2003). Vitamin E modulates radiation-induced oxidative damage in mice fed a high lipid diet. J. Biochem. Mol. Bio. 36 (2), 190-195.

Takagi S (1985). Determination of Green Leaf Caroteniods. Agric. Bio. Chem. 49(4), 1211- 1213

Whitehead D, Dibb CH, Hartley RD (1983). Bound phenolic compounds in water extracts of soil, plant roots and leaf litter. Soil Bio. Biochem. $15,133-136$ 